\title{
BMJ Open The extent to which family physicians record their patients' exercise in medical records: a scoping review
}

\author{
Cliff Lindeman (D , , ${ }^{1,2}$ Ashley McCurdy, ${ }^{2}$ Carminda G Lamboglia, ${ }^{2}$ \\ Brendan Wohlers, ${ }^{2}$ Anh N Q Pham, ${ }^{1}$ Allison Sivak, ${ }^{3}$ John C Spence (D) ${ }^{2}$
}

To cite: Lindeman C, McCurdy A, Lamboglia CG, et al. The extent to which family physicians record their patients' exercise in medical records: a scoping review. BMJ Open 2020;10:e034542. doi:10.1136/ bmjopen-2019-034542

- Prepublication history and additional material for this paper are available online. To view these files, please visit the journal online (http://dx.doi. org/10.1136/bmjopen-2019034542).

Received 26 September 2019 Revised 10 January 2020 Accepted 15 January 2020

Check for updates

(C) Author(s) (or their employer(s)) 2020. Re-use permitted under CC BY-NC. No commercial re-use. See rights and permissions. Published by BMJ.

${ }^{1}$ Department of Family Medicine University of Alberta, Edmonton, Alberta, Canada

${ }^{2}$ Faculty of Kinesiology, Sport, and Recreation, University of Alberta, Edmonton, Alberta, Canada

${ }^{3}$ Coutts Library, University of Alberta, Edmonton, Alberta, Canada

Correspondence to Professor John C Spence; jc.spence@ualberta.ca

\section{ABSTRACT}

Objective Exercise is an effective modality for the prevention and treatment of chronic conditions and family physicians are the healthcare providers tasked to manage patients' chronic disease status. However, little is known about the exercise documentation in family-physician records. Therefore, a scoping review was conducted to describe family-physician-recorded exercise-related advice to patients in electronic medical records.

Design Scoping review.

Setting Primary care clinics.

Search strategy PubMed, Medline, SPORTDiscus, Google, Dissertations \& Theses Global, OCLC PapersFirst (via First Search) and included references were searched between 1 January 1990 and 10 June 2018. Extracted information included year, geographic origin, data input structure, input frequency and content of exercise inputs in family physicians' electronic medical records. The primary outcomes are the structure, purpose and frequency of inputs.

Results Of a possible 1758 documents, 83 remained after a title and abstract scan and 22 after a full-text review. These documents included 32 findings of physical activity/ exercise medical record documentation: counselling/ advising patients $(50.0 \%)$, status ( $12.5 \%)$, embedded questionnaires $(12.5 \%)$, status as a risk factor $(12.5 \%)$, health promotion documentation $(6.3 \%)$, inactivity status (3.1\%) and grading (3.1\%). The frequency of exercise inputs in primary care records vary from as low as $0.4 \%$ of patients with documentation of physical activity health promotion inputs to as high as $87.8 \%$ of patients with exercise or physical activity status recorded. The majority of included documents $(63.6 \%)$ were focused on patients with identified chronic conditions.

Conclusion The findings suggest that the structure and purpose of exercise documentation is often unclear or unspecified. Studies that present exercise information from family-physician medical records tend to focus on patients with specific chronic conditions and present little detail about the field from which information was extracted. The review found that the proportion of patients with physical activity or exercise information is often less than half.

\section{BACKGROUND}

Physical inactivity is the fourth leading risk factor of global mortality and is a known prominent risk factor for many chronic

\section{Strengths and limitations of this study}

- Medical record systems continue to evolve and there is a subsequent need to understand what is documented in them to inform quality-improvement initiatives.

- This review is the first to identify the content of exercise recording in family-physician electronic medical records.

- This review included published studies to provide a comprehensive response to the identified research questions.

- This review describes the context and input structure of family physicians documenting exercise information in electronic medical records.

- Due to the variability in exercise and physical activity terminology across countries and settings, documents may have been missed.

conditions. ${ }^{12}$ It is well documented that exercise is effective in preventing and treating many chronic conditions and offers benefits comparable to pharmacologic interventions, yet, exercise is under prescribed in the clinical setting. ${ }^{3}$ This may be due to clinicians' apprehension of physical activity counselling effectiveness ${ }^{4}$ and/or renumeration structures in health systems. ${ }^{5}$ Regardless, primary care providers are in a unique position to provide such counselling because of their ability to reach a large portion of the overall population and their role as trusted sources of health information as well as the ability to refer to a range of related health professionals available within many primary care clinics. ${ }^{6}$

Because of a historic lack of comprehensiveness, ${ }^{7}$ initiatives have recently emerged that use electronic medical record (EMR) information inputted by primary care providers to assess the quality of care provided for representative patient population samples. ${ }^{8}$ Given that primary care EMR databases were developed to support healthcare management and to include information about patient history 
and associated clinician notes, they are a rich populationlevel source of health information that can be collected and standardised for secondary analyses and surveillance purposes. ${ }^{9}$ However, little research exists about the nature of EMR exercise inputs by family physicians and no review has examined the structure, content and frequency of these inputs. This is surprising since the WHO's Global Action Plan on Physical Activity 2018-2030 identified the importance of healthcare providers in promoting physical activity with the aid of digital innovations. ${ }^{10}$

Heeding this advice, we conducted a scoping review to determine the frequency and depth of related research. Based on studies that used EMR data for primary data collection, we posed the following three questions: What types of exercise information are family physicians recording in EMRs? Is there available literature describing the structure of such inputs? How often is this information inputted into EMRs?

Given the broad nature of these questions, we elected to use a scoping review as the most suitable approach for summarising acquired information. Specifically, a scoping review provides an appropriate methodology for identifying gaps in the literature and is deemed particularly relevant for addressing research topics with limited or emerging evidence. ${ }^{11}$

\section{METHODS}

PROSPERO does not currently accept registrations for scoping reviews, literature reviews, or mapping reviews, thus the protocol for this review was not registered. Instead, this review followed recommendations for scoping reviews, ${ }^{11} 12$ and the Preferred Reporting Items for Systematic reviews and Meta-Analyses extension for Scoping Reviews (PRISMA-ScR) ${ }^{13}$ The completed PRIMSA-ScR checklist is included as a supplementary document (online supplementary appendix A) and a copy of the review protocol is available on request from the corresponding author.

Although 'physical activity', 'activity' and 'exercise' are not synonymous, they are often used interchangeably in clinical settings. ${ }^{14}$ Therefore, when describing the content of the EMR, the results will refer to the term as used in the original source document.

The search included a three-stage approach conducted by an expert librarian (AS), who developed the search strategy. First, MEDLINE (Ovid), SPORTDiscus and PubMed were accessed using terms from the research questions including: ("primary care physician*", "physician*", "exercise", "physical activity", "exercise therapy", "exercise movement techniques", "medical records" and "electronic health records". The search was completed on 10 June 2018. Second, "family physician AND exercise AND record" was searched in the Grey Literature Database (http://www.greylit.org), 10 December 2018. Third, Dissertations \& Theses Global and OCLC PapersFirst (via First Search) were used to identify dissertations, theses, and conference papers/abstracts and the first 100
Google searches were reviewed for: "+physician +exercise+record", "+doctor +exercise+record", "+general practitioner+exercise +record" with repeat replace with "+exercise" and "+physical activity". All searches were restricted to the date range of 1 January 1990 and 10 June 2018. The starting date of 1990 was chosen as it was unlikely that EMRs were used to document physical activity information prior to this date. The search strategy is included as online supplementary appendix B.

To be included for full-text review, titles and/or abstracts had to detail: (1) exercise or active or activity or physical activity; (2) primary care or primary care physician or primary healthcare physician or family doctor or doctor; (3) medical record or record or EMR or health record or medical health record. Documents that did not include all three criteria were excluded.

All document titles and abstracts were independently reviewed by two reviewers; CL reviewed all results and a combination of: ANQP, BW, AM and CGL each reviewed $25 \%$. The reviewers recorded whether a document should be considered for full-text review. All discrepancies were reviewed in person, which provided the opportunity to discuss challenges and uncertainties that arose during the study selection.

Data extraction was conducted using a codebook developed by: CL, AM and JCS. It consisted of specific categories: characteristics of the document (ie, author, year of study, geographic location, publication type and study design); characteristics of the patient and provider sample (ie, age, sex, type of population, sample size, general population or specific chronic condition); whether information was documented in an EMR; content recorded (ie, advice, fitness levels, current behaviour and past behaviour); frequency of patients with recorded information in medical records; structure of exercise recording (ie, unstructured text, drop-down menu, e-template and unspecified); and author recommendations or statements regarding physical activity recording by family physicians. Two reviewers extracted data from the studies and subsequently met to compare the results and resolve discrepancies.

Data were coded and frequency counts were performed for each categorical variable. The main findings were recorded as text and subjected to content analysis. ${ }^{15}$ Specifically, the primary meaning of the text was categorised according to the differing purposes stated (ie, advice, fitness levels, current behaviour, past behaviour or structure of input). All data relevant to the study are included in the article or uploaded as online supplementary information.

\section{PATIENT AND PUBLIC INVOLVEMENT}

There was no patient or public involvement in this review. 


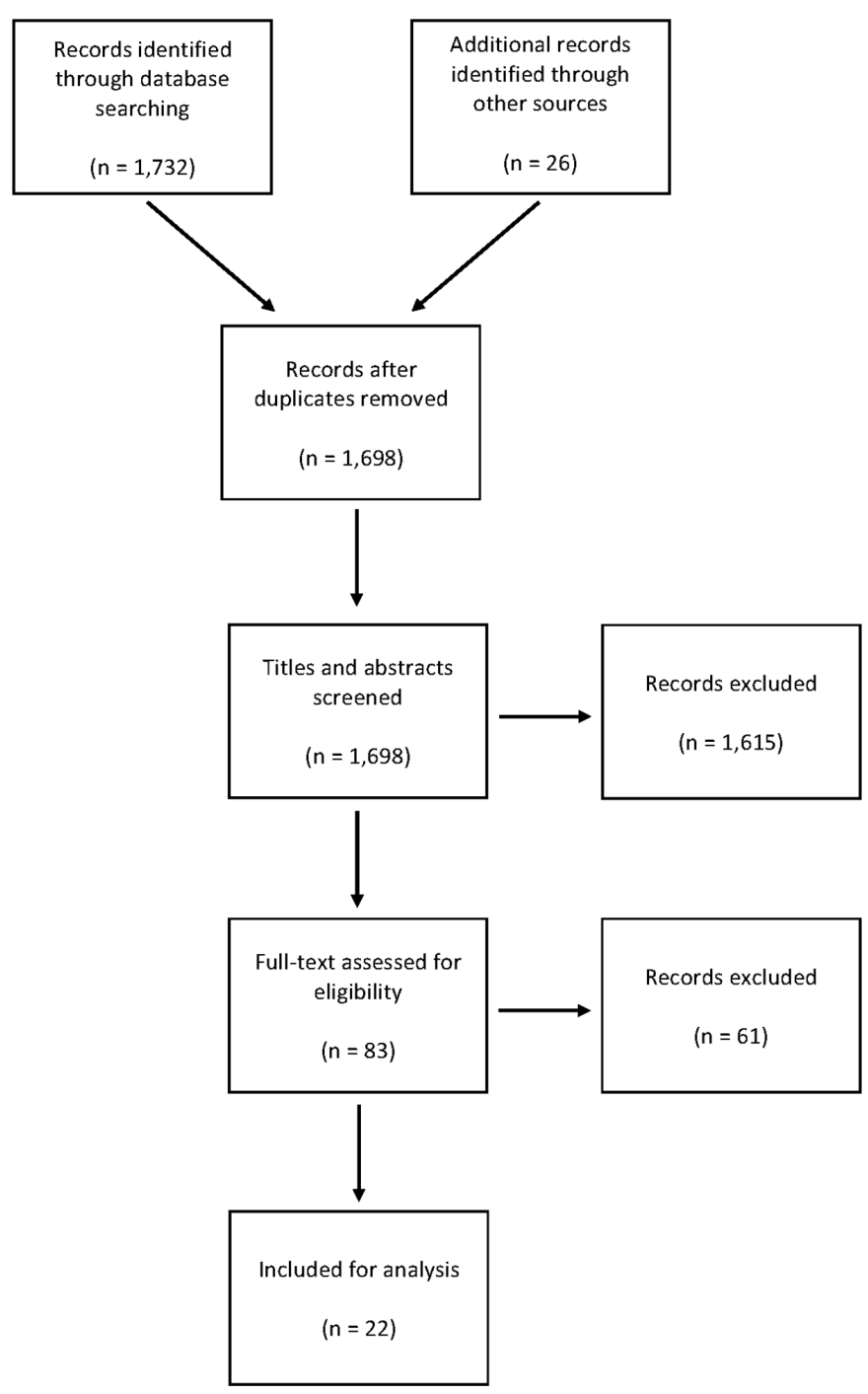

Figure 1 Selection of sources for scoping review.

\section{RESULTS}

In accordance with PRISMA-ScR guidelines, figure 1 presents a flow chart of the search and selection process. The initial search of databases $(n=1732)$ and manual searches $(\mathrm{n}=26)$ resulted in 1758 potential includes. After removal of duplicates, 1698 documents were considered for title and abstracts screening; a further 1615 documents did not satisfy the inclusion criteria and were subsequently excluded. The remaining 83 documents were subjected to full-text review, which resulted in 22 documents and 32 discrete findings (ie, determined as inputs with discrete, independent purposes) being included in the final analysis (a complete document reference list is included as online supplementary appendix C). Detailed in table 1, with aggregated results provided in table 2 , the majority of the documents originated from Europe $(45.5 \%)$, were cross-sectional in design $(52.3 \%)$ and focused on patients with chronic conditions $(63.6 \%)$. Nearly half $(45.5 \%)$ of the documents mentioned recording exercise or physical activity in EMR, $11(50.0 \%)$ specified 'medical record' or 'record', which may or may not be electronic. For example, Asnani states, 'Data were collected retrospectively from a total of 125 medical records ${ }^{\prime 16}$ (p. 178).

As table 3 outlines, 16 findings $(50.0 \%)$ detailed counselling/advice on physical activity or exercise, 4 findings $(12.5 \%)$ referred to exercise/physical activity status and 4 findings $(12.5 \%)$ had physical activity or exercise documented as a risk factor. Two findings (6.3\%) used the Exercise as a Vital Sign questionnaire and (6.3\%) used the General Practice Physical Activity Questionnaire. Two findings $(6.3 \%)$ discussed health promotion; one finding $(3.1 \%)$ recorded exercise/physical activity grading and one finding $(3.1 \%)$ noted inactivity status.

Most findings presented a proportion of patients with an entry. For example, Mattar indicated 'Physicians provided ... exercise counselling for $40 \%$ of patients with documented obesity ${ }^{17}$ (p. 71). The range of patients with inputs varied greatly; the number of patients who received counselling/advice on physical activity or exercise ranged from $1 \%$ of patients to $78.8 \%$. Table 3 presents the range of patients with inputs by content.

Table 4 outlines the structure of the medical record inputs. The majority $(65.6 \%)$ did not specify the structure of input. For example, Lieshout explained that physical activity capacity and physical activity advice "could be collected by extraction from medical records"18 ( $p$. 3 ), which does not describe the fields from which physical activity data was extracted be it open-text fields, drop-down menus, templates embedded within EMRs or another structure. While $12.5 \%$ used a structured questionnaire embedded within the EMR, 9.4\% were found in 'medical notes', $6.3 \%$ were documented in an unstructured open-text format, and $6.3 \%$ used an e-template embedded within the EMR.

\section{DISCUSSION}

We asked three questions to understand the type of information family physicians recorded in EMRs, the structure of those inputs, and how many individual EMRs had the information recorded. This is of particular relevance as EMRs are being implemented in family medicine clinics; for example, in 2013, 64\% of Canadian primary care physicians use EMRs compared with $23 \%$ in $2006 .{ }^{19}{ }^{20}$ Because of the wide adoption of medical records in primary healthcare, the low frequency of documents detailing inputs regarding exercise or physical activity is surprising.

As to the question on the structure of input, our review found little specificity in how exercise information was entered in the EMRs. It was often unclear if the input structure was documented in the EMR notes, an embedded template, a dedicated field, or if the record had a dedicated structured specified field such as a dropdown menu dedicated to physical activity status inputs. The type of information family physicians recorded in EMRs varied from completing embedded questionnaires (eg, General Practice Physical Activity Questionnaire) to providing advice, health promotion discussions, current status, grading (presumably a measure of fitness but this 
Table 1 Characteristics of included documents $(n=22)$

\begin{tabular}{|c|c|c|c|c|c|}
\hline \# & Author; year; countries & Method & $\begin{array}{l}\text { Patient } \\
\text { population }\end{array}$ & $\begin{array}{l}\text { Family physician } \\
\text { ( } n \text {; \% male; years } \\
\text { of practice M) }\end{array}$ & $\begin{array}{l}\text { Patient ( } \mathbf{n} ; \% \\
\text { male; age in years } \\
\text { M) }\end{array}$ \\
\hline 1 & $\begin{array}{l}\text { Lieshout; 2012; Austria, Belgium, } \\
\text { England, France, Germany, } \\
\text { Netherlands, Slovenia and } \\
\text { Switzerland }\end{array}$ & $\begin{array}{l}\text { Cross-sectional } \\
\text { research article }\end{array}$ & $\begin{array}{l}\text { Patients with } \\
\text { coronary heart } \\
\text { disease }\end{array}$ & $\begin{array}{l}\text { Unspecified; } \\
\text { unspecified; } \\
\text { unspecified }\end{array}$ & $2960 ; 67 \% ; 68.7$ \\
\hline 3 & $\begin{array}{l}\text { Gulliford; 1996; Barbados, Trinidad } \\
\text { and Tobago, and Tortola }\end{array}$ & $\begin{array}{l}\text { Cross-sectional } \\
\text { research article }\end{array}$ & $\begin{array}{l}\text { Patients with } \\
\text { diabetes }\end{array}$ & $\begin{array}{l}\text { Unspecified; } \\
\text { unspecified; } \\
\text { unspecified }\end{array}$ & $\begin{array}{l}1661 ; 33.3 \% \\
\text { unspecified }\end{array}$ \\
\hline 4 & Sun; 1995; China & $\begin{array}{l}\text { Cross-sectional } \\
\text { research article }\end{array}$ & $\begin{array}{l}\text { Patients with } \\
\text { cardiovascular } \\
\text { disease }\end{array}$ & $\begin{array}{l}\text { Unspecified; } \\
\text { unspecified; } \\
\text { unspecified }\end{array}$ & $\begin{array}{l}\text { 4520; unspecified; } \\
\text { unspecified }\end{array}$ \\
\hline 6 & Grant; 2013; USA & $\begin{array}{l}\text { Pre-post research } \\
\text { article }\end{array}$ & $\begin{array}{l}\text { General } \\
\text { population }\end{array}$ & $\begin{array}{l}\text { 1196; unspecified; } \\
\text { unspecified }\end{array}$ & $\begin{array}{l}696267 ; 47.7 \% \\
51.4\end{array}$ \\
\hline 7 & Allenby; 2016; Australia & $\begin{array}{l}\text { Cross-sectional } \\
\text { research article }\end{array}$ & $\begin{array}{l}\text { Patients with } \\
\text { cardiovascular } \\
\text { disease }\end{array}$ & $\begin{array}{l}\text { 282; unspecified; } \\
\text { unspecified }\end{array}$ & $282 ; 86.8 \% ; 69.7$ \\
\hline 8 & Wilson; 1992; England & $\begin{array}{l}\text { Intervention research } \\
\text { article }\end{array}$ & $\begin{array}{l}\text { General } \\
\text { population }\end{array}$ & $\begin{array}{l}\text { Unspecified; 81\%; } \\
\text { unspecified }\end{array}$ & $\begin{array}{l}\text { Unspecified; } \\
\text { unspecified; } \\
\text { unspecified }\end{array}$ \\
\hline 9 & Crossen; 2000; New Zealand & $\begin{array}{l}\text { Cross-sectional } \\
\text { research article }\end{array}$ & $\begin{array}{l}\text { Patients with } \\
\text { coronary heart } \\
\text { disease }\end{array}$ & $\begin{array}{l}\text { 21; unspecified; } \\
\text { unspecified }\end{array}$ & $326 ; 59.8 \% ; 68.6$ \\
\hline 12 & Lange; 2007; Denmark & $\begin{array}{l}\text { Pre-post research } \\
\text { article }\end{array}$ & $\begin{array}{l}\text { Patients with } \\
\text { COPD }\end{array}$ & $\begin{array}{l}\text { 154; unspecified; } \\
\text { unspecified }\end{array}$ & $4943 ; 44.9 \% ; 70.4$ \\
\hline 13 & Pajak; 2010; Poland & $\begin{array}{l}\text { Intervention research } \\
\text { article }\end{array}$ & $\begin{array}{l}\text { Patients with } \\
\text { cardiovascular } \\
\text { disease }\end{array}$ & $\begin{array}{l}\text { Unspecified; } \\
\text { unspecified; } \\
\text { unspecified }\end{array}$ & $4421 ; 45.8 \% ; 44.7$ \\
\hline 14 & Doubova; 2015; Mexico & $\begin{array}{l}\text { Cross-sectional } \\
\text { research article }\end{array}$ & $\begin{array}{l}\text { Patients with } \\
\text { osteoarthritis }\end{array}$ & $\begin{array}{l}\text { Unspecified; } \\
\text { unspecified; } \\
\text { unspecified }\end{array}$ & $8991 ; 31 \% ; 60$ \\
\hline 15 & Mattar; 2017; USA & $\begin{array}{l}\text { Cross-sectional } \\
\text { research article }\end{array}$ & $\begin{array}{l}\text { Patients with } \\
\text { obesity }\end{array}$ & $\begin{array}{l}\text { 29; unspecified; } \\
\text { unspecified }\end{array}$ & $3868 ; 40 \% ; 48.6$ \\
\hline 16 & AuYoung; 2016; USA & Review article & $\begin{array}{l}\text { General } \\
\text { population }\end{array}$ & $\begin{array}{l}\text { Unspecified; } \\
\text { unspecified; } \\
\text { unspecified }\end{array}$ & $\begin{array}{l}\text { Unspecified; } \\
\text { unspecified; } \\
\text { unspecified }\end{array}$ \\
\hline 17 & Heron; 2014; Ireland & $\begin{array}{l}\text { Mixed-method } \\
\text { research article }\end{array}$ & $\begin{array}{l}\text { General } \\
\text { population }\end{array}$ & $\begin{array}{l}\text { 11; unspecified; } \\
\text { unspecified }\end{array}$ & $\begin{array}{l}\text { 192; unspecified; } \\
\text { unspecified }\end{array}$ \\
\hline 18 & Coleman; 2012; USA & $\begin{array}{l}\text { Intervention research } \\
\text { article }\end{array}$ & $\begin{array}{l}\text { General } \\
\text { population }\end{array}$ & $\begin{array}{l}\text { Unspecified; } \\
\text { unspecified; } \\
\text { unspecified }\end{array}$ & $\begin{array}{l}\text { 1793385; 43.3\%; } \\
\text { unspecified }\end{array}$ \\
\hline 19 & Chatterjee; 2017; UK & $\begin{array}{l}\text { Cross-sectional } \\
\text { research article }\end{array}$ & $\begin{array}{l}\text { General } \\
\text { population }\end{array}$ & $\begin{array}{l}\text { 1013; unspecified; } \\
22\end{array}$ & $\begin{array}{l}\text { Unspecified; } 43 \% \text {; } \\
\text { unspecified }\end{array}$ \\
\hline
\end{tabular}




\begin{tabular}{|c|c|c|c|c|c|}
\hline \# & Author; year; countries & Method & $\begin{array}{l}\text { Patient } \\
\text { population }\end{array}$ & $\begin{array}{l}\text { ( } n \text {; \% male; years } \\
\text { of practice } M \text { ) }\end{array}$ & $\begin{array}{l}\text { male; age in years } \\
\text { M) }\end{array}$ \\
\hline 20 & $\begin{array}{l}\text { Ludt; 2011; Austria, Belgium, } \\
\text { Finland, France. Germany, } \\
\text { Netherlans, Slovenia, Switzerland } \\
\text { and UK }\end{array}$ & $\begin{array}{l}\text { Cross-sectional } \\
\text { research article }\end{array}$ & $\begin{array}{l}\text { Patients with } \\
\text { cardiovascular } \\
\text { disease }\end{array}$ & $\begin{array}{l}\text { 268; unspecified; } \\
\text { unspecified }\end{array}$ & $3723 ; 70.5 \% ; 66$ \\
\hline 21 & Neighbor; 1991; USA & $\begin{array}{l}\text { Cross-sectional } \\
\text { research article }\end{array}$ & $\begin{array}{l}\text { General } \\
\text { population }\end{array}$ & $\begin{array}{l}\text { 120; } 62 \% ; \\
\text { unspecified }\end{array}$ & $1528 ; 28 \% ; 36$ \\
\hline
\end{tabular}

COPD, chronic obstructive pulmonary disease.

was not clear) and as a risk factor in combination with other patient risk factors (eg, BMI level and smoking status). This indicates that the plausible topics for input in the EMRs is quite varied. Thus, designated sections in EMRs are needed to easily record exercise-related information. For instance, the specifics on the physical activity advice provided to patients as well as their current physical activity status should be regularly recorded to support

\begin{tabular}{|c|c|c|}
\hline Geographic location $(n=22)$ & $\mathbf{N}$ & $\%$ \\
\hline Europe & 10 & 45.5 \\
\hline North America & 8 & 36.4 \\
\hline Australia & 3 & 13.6 \\
\hline Asia & 1 & 4.5 \\
\hline \multicolumn{3}{|l|}{ Publication status $(\mathrm{n}=22)$} \\
\hline Published & 22 & 100.0 \\
\hline Unpublished & 0 & 0.0 \\
\hline \multicolumn{3}{|l|}{ Publication type ( $\mathrm{n}=22)$} \\
\hline Research article & 21 & 95.5 \\
\hline Review article & 1 & 4.5 \\
\hline \multicolumn{3}{|l|}{ Research article design $(n=21)$} \\
\hline Cross-sectional & 11 & 52.3 \\
\hline Intervention & 3 & 14.3 \\
\hline Pre-post & 3 & 14.3 \\
\hline Mixed-method & 2 & 9.5 \\
\hline Observational & 1 & 4.8 \\
\hline Randomised control trial & 1 & 4.8 \\
\hline
\end{tabular}

Patient population $(\mathrm{n}=22)$

Patients who have a specific chronic $14 \quad 63.6$

condition

General public

$8 \quad 36.4$

\begin{tabular}{lrr} 
Medical record format $(n=22)$ & & \\
Electronic & 10 & 45.5 \\
Unclear & 11 & 50.0 \\
Electronic and paper & 1 & 4.5 \\
\hline
\end{tabular}

family physicians in subsequent conversations promoting active lifestyles with patients. Further research is needed to determine whether or not the implementation of structured templates for exercise in EMRs influences physician's exercise documentation practices and what format or variables in such templates may be most effective.

The frequency of exercise and/or physical activity documentation varied greatly across studies. The largest variation was for counselling/advice on physical activity, which ranged from $1 \%$ of patients with an input in medical record to $78.8 \%$. Of the findings that presented a frequency or proportion of exercise or physical activity, $10(33.3 \%)$ reported more than $50 \%$ of the sample had any record (see online supplementary appendix D). Although variation exists across contexts and patient population samples, more than half of patients do not appear to have any documentation of exercise or physical activity in EMRs. A potential explanation for the low

Table 3 Content recorded in medical records and the range of patients with inputs $\left(\mathrm{n}_{\text {findings }}=32\right.$ )

\begin{tabular}{|c|c|c|}
\hline Content record & $\begin{array}{l}\text { Frequency of } \\
\text { findings }(n ; \%)\end{array}$ & $\begin{array}{l}\text { Range of } \\
\text { patients with } \\
\text { inputs (\%) }\end{array}$ \\
\hline $\begin{array}{l}\text { Counselling/advice on } \\
\text { physical activity/ exercise }\end{array}$ & $16 ; 50.0$ & $1.0-78.8$ \\
\hline $\begin{array}{l}\text { Exercise/ physical activity } \\
\text { status }\end{array}$ & $4 ; 12.5$ & $12.4-87.8$ \\
\hline $\begin{array}{l}\text { Physical activity/exercise } \\
\text { documented as risk factor }\end{array}$ & $4 ; 12.5$ & $25.0-55.9$ \\
\hline EVS Questionnaire & $2 ; 6.3$ & $21.0-86.0$ \\
\hline $\begin{array}{l}\text { Exercise documentation/ } \\
\text { health promotion }\end{array}$ & $2 ; 6.3$ & $0.4-25.0$ \\
\hline GPPAQ Questionnaire & $2 ; 6.3$ & $10-78$ \\
\hline $\begin{array}{l}\text { Exercise/ physical activity } \\
\text { grading }\end{array}$ & $1 ; 3.1$ & 8.0 \\
\hline Inactivity status & $1 ; 3.1$ & $30.0-47.0$ \\
\hline
\end{tabular}

EVS, Exercise as a Vital Sign; GPPAQ, General Practice Physical Activity Questionnaire. 


\begin{tabular}{|c|c|c|}
\hline Structure of input $(n=34)$ & Frequency & $\%$ \\
\hline Unspecified & 21 & 65.6 \\
\hline $\begin{array}{l}\text { Structured questionnaire } \\
\text { embedded within EMR }\end{array}$ & 4 & 12.5 \\
\hline Medical record notes & 3 & 9.4 \\
\hline Unstructured open-text & 2 & 6.3 \\
\hline $\begin{array}{l}\text { E-template embedded within } \\
\text { EMR }\end{array}$ & 2 & 6.3 \\
\hline
\end{tabular}

EMR, electronic medical record.

proportion of exercise inputs may be due to payment structures that incentivize inputs. A fee-for-service model encourages a one problem per visit approach to care while sessional contracts may provide flexibility for managing complex time-consuming patient care. ${ }^{21}$ Future reviews should consider physician renumeration in relation to EMR input frequencies. ${ }^{22}$

Patients with diagnosed chronic diseases (eg, cardiovascular disease and obesity) are more likely than otherwise healthy patients to receive exercise counselling from physicians. ${ }^{1723}$ For instance, Mattar et al, found that physicians were more likely to provide exercise counselling for patients with documented obesity (40\%) compared to patients with undocumented obesity $(29 \%) .{ }^{17}$ Thus, exercise is recorded more frequently once patients have diagnosed chronic conditions rather than as a treatment to prevent the onset of a chronic condition. This could be considered a more reactive approach to healthcare when in fact a more proactive, preventative approach may reduce chronic disease occurrence, such as increasing physical activity levels in patients who were deemed inactive. ${ }^{24}$

This review has some limitations that should be acknowledged. First, the information that family physicians recorded in EMRs and subsequently presented in published documents was scant. As Leishout $e t$ al found, 'Advice on physical activity had low scores... it remains uncertain whether such advice had been provided but not recorded. ${ }^{20}$ Thus, more research is required to better understand how exercise is recorded in EMRs and whether entries are located in notes or a structured field designed to support family physicians as they provide care for patients. Although EMR systems often capture data for a substantial portion of the general population, ${ }^{25}$ the proportion of undocumented physical activity and exercise discussions are not known. Second, 21 of the 22 $(95.5 \%)$ included documents are from the western developed world. Therefore, the relevance of our findings for non-developed countries is questionable.

In summary, the available research suggests that the structure and purpose of exercise documentation in EMRs is often unclear or unspecified. Studies that present exercise information from family physician medical records tend to focus on patients with specific chronic conditions, present little detail about the field from which information was extracted, and indicate that the proportion of patients with physical activity or exercise information is often less than half. Ultimately, more audits of EMR exercise recording practices are needed that outline disparities across systems and capabilities.

Contributors CL, JCS, AS and AM formulated the project idea and developed the working protocol. $A S$ and $C L$ acquired the data for the scoping review. $C L$, AM, ANQP, CGL and BW completed title and abstract review, full-text review and systematic data extraction. CL and JCS act as guarantors of the work. All authors provided meaningful contributions and have approved the final version to be published.

Funding The authors have not declared a specific grant for this research from any funding agency in the public, commercial or not-for-profit sectors.

Competing interests None declared.

Patient consent for publication Not required.

Provenance and peer review Not commissioned; externally peer reviewed.

Data availability statement All data relevant to the study are included in the article or uploaded as supplementary information. All data in the scoping review were published through journals. References to all included articles can be found in Appendix C.

Open access This is an open access article distributed in accordance with the Creative Commons Attribution Non Commercial (CC BY-NC 4.0) license, which permits others to distribute, remix, adapt, build upon this work non-commercially, and license their derivative works on different terms, provided the original work is properly cited, appropriate credit is given, any changes made indicated, and the use is non-commercial. See: http://creativecommons.org/licenses/by-nc/4.0/.

\section{ORCID iDs}

Cliff Lindeman http://orcid.org/0000-0003-2851-265X

John C Spence http://orcid.org/0000-0001-8485-1336

\section{REFERENCES}

1 Warburton DER, Bredin SSD. Health benefits of physical activity: a systematic review of current systematic reviews. Curr Opin Cardiol 2017;32:541-56.

2 World Health Organization. Global strategy on diet, physical activity, and health, 2019. Available: https://www.who.int/dietphysicalactivity/ pa/en/ [Accessed 4 Apr 2019].

3 Hoffmann TC, Maher CG, Briffa T, et al. Prescribing exercise interventions for patients with chronic conditions. CMAJ 2016:188:510-8.

4 Persson G, Brorsson A, Ekvall Hansson E, et al. Physical activity on prescription (PAP) from the general practitioner's perspective - a qualitative study. BMC Fam Pract 2013;14:1-8.

5 Diehl K, Mayer M, Mayer F, et al. Physical activity counseling by primary care physicians: attitudes, knowledge, implementation, and perceived success. J Phys Act Health 2015;12:216-23.

6 AuYoung M, Linke SE, Pagoto S, et al. Integrating physical activity in primary care practice. Am J Med 2016;129:1022-9.

$7 \mathrm{ClHI}$. Chronic disease management in primary health care: a demonstration of EMR data for health system monitoring, 2014. Available: https://secure.cihi.ca/free_products/Burden-of-ChronicDiseases_PHC_2014_AiB_EN-web.pdf

8 Queenan JA, Williamson T, Khan S, et al. Representativeness of patients and providers in the Canadian primary care sentinel surveillance network: a cross-sectional study. CMAJ Open 2016;4:28-32.

9 Birtwhistle R, Williamson T. Primary care electronic medical records: a new data source for research in Canada. Can Med Assoc $J$ 2015;187:239-40.

10 World Health Organization. Global action plan on physical activity 2018-2030: more active people for a healthier world 2018.

11 Levac D, Colquhoun H, O'Brien KK. Scoping studies: advancing the methodology. Implement Sci 2010;5:69-77.

12 Arksey H, O'Malley L. Scoping studies: towards a methodological framework. Int J Soc Res Methodol 2005;8:19-32.

13 Tricco AC, Lillie E, Zarin W, et al. PRISMA extension for scoping reviews (PRISMA-ScR): checklist and explanation. Ann Intern Med 2018;169:467-73. 
14 Ceria-Ulep CD, Tse AM, Serafica RC. Defining exercise in contrast to physical activity. Issues Ment Health Nurs 2011;32:476-8.

15 Hsieh H-F, Shannon SE. Three approaches to qualitative content analysis. Qual Health Res 2005;15:1277-88.

16 Asnani M, Brown P, O'Connor D, et al. A clinical audit of the quality of care of hypertension in general practice. West Indian Med $J$ 2014:54:176-80.

17 Mattar A, Carlston D, Sariol G, et al. The prevalence of obesity documentation in primary care electronic medical records. are we acknowledging the problem? Appl Clin Inform 2017;8:67-79.

18 van Lieshout J, Grol R, Campbell S, et al. Cardiovascular risk management in patients with coronary heart disease in primary care: variation across countries and practices. An observational study based on quality indicators. BMC Fam Pract 2012;13:96.

19 Chang F, Gupta N. Progress in electronic medical record adoption in Canada. Can Fam Physician 2015;61:1076-84.

20 Zelmer J, Hagens S. Advancing primary care use of electronic medical records in Canada. HRO-ORS 2014;2.
21 The College of Family Physicians of Canada. Best advice: Physician renumeration in a patient's medical home, 2016. Available: https:// patientsmedicalhome.ca/files/uploads/BAG_Rem_ENG_WEB_rev.pdf [Accessed 13 Nov 2019].

22 de Souto Barreto P, Cesari M, Andrieu S, et al. Physical activity and incident chronic diseases: a longitudinal observational study in 16 European countries. Am J Prev Med 2017;52:373-8.

23 Allenby A, Kinsman L, Tham R, et al. The quality of cardiovascular disease prevention in rural primary care. Aust $J$ Rural Health 2016;24:92-8.

24 Sun WY, Chen WW, Chen L, et al. Difference of lifestyle advice between traditional Chinese medical doctors (TCMDs) and westernstyle medical doctors (WSMDs) in people's Republic of China. Patient Educ Couns 1995;25:311-6.

25 Canadian Primary Care Sentinel Surveillance Network. CPCSSN data for research, 2019. Available: http://cpcssn.ca/research-resources/ cpcssn-data-for-research/ [Accessed 13 Nov 2019]. 